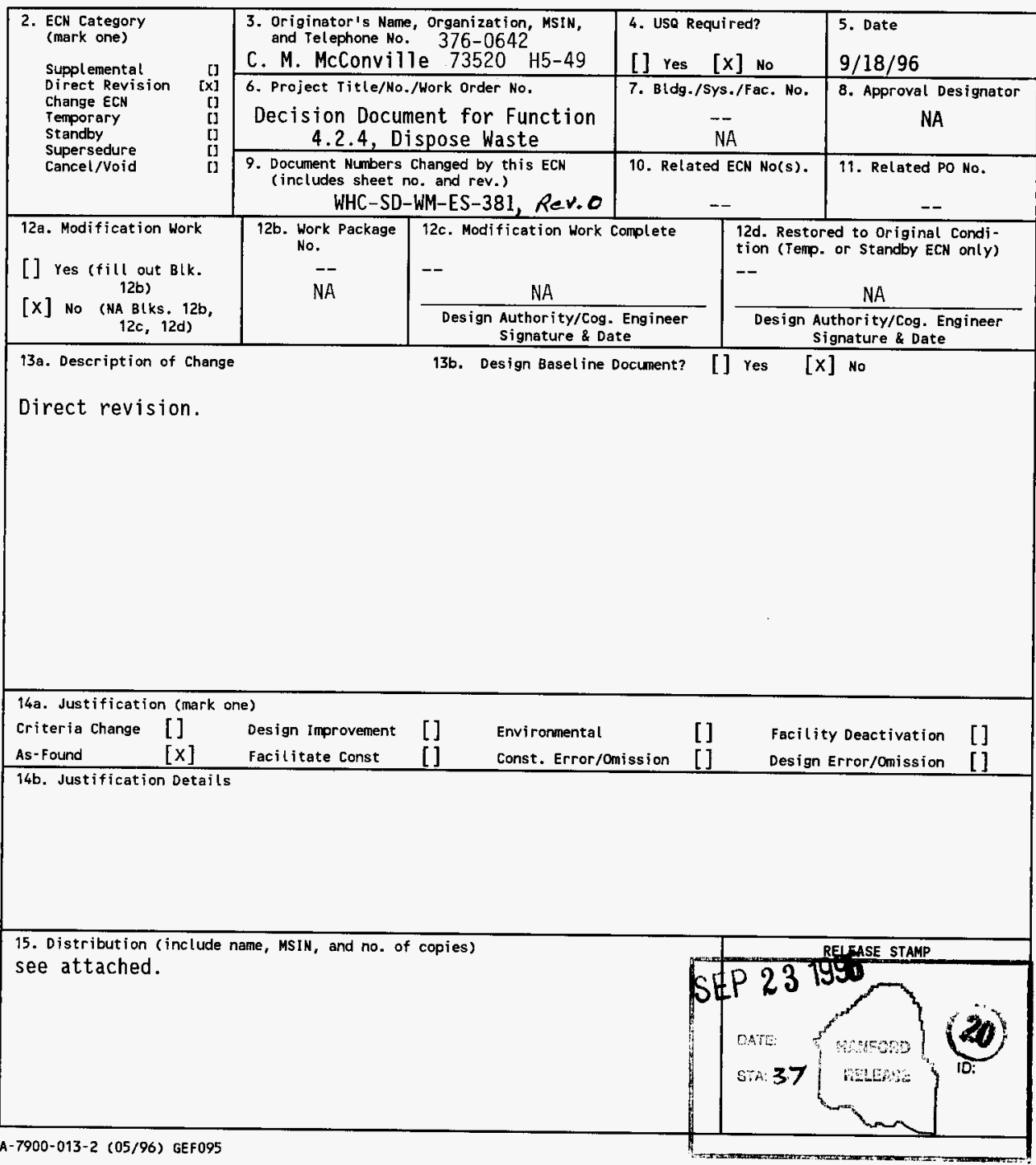




\begin{tabular}{|c|c|c|c|c|c|}
\hline $\begin{array}{l}\text { 16. Design } \\
\text { Verification } \\
\text { Required }\end{array}$ & 17. Cost In & 17. Cost Impact & & & 18. Schedule Impact (days) \\
\hline [] Yes & Additional & $\$$ & Additional & $\$$ & Improvement \\
\hline [] No & Savings & $\$$ & Savings & $\$$ & Delay \\
\hline
\end{tabular}

19. Change 1mpact Review: Indicate the related documents (other than the engineering documents identified on side 1 ) that will be affected by the change described in Block 13. Enter the affected document number in Block 20.

SDD/DD
Functional Design Criteria
Operating Specification
Criticality Specification
Conceptual Design Report
Equipment Spec.
Const. Spec.
Procurement Spec.
Vendor Information
OM Manual
FSAR/SAR
Safoty Equipment List
Radiation Work Permit
Environmental impact Statement
Environmental Report
Environmental Permit

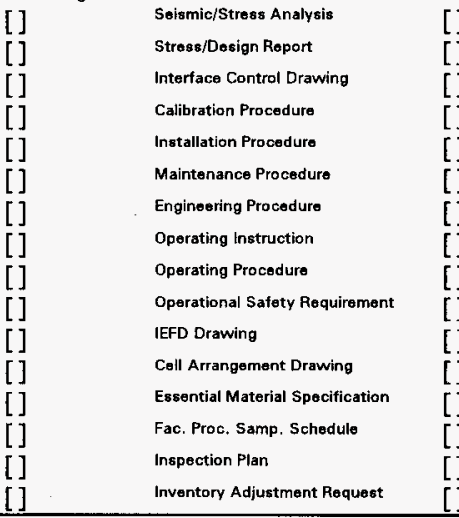

Tank Calibration Manual

[] Health Physics Procedure

[] Spares Multiple Unit Listing

Test Procedures/Specification

Component Index

[] ASME Coded Item

[] Human Factor Consideration

Electric Circuit Schedule

[] ICRS Procedure

[] Process Control Manual/Plan

Tickler File

20. Other Affected Documents: (NOTE: Documents listed below will not be revised by this ECN.) Signatures below indicate that the signing organization has been notified of other affected docunents listed below.

Document Number/Revision

Document Number/Revision

Document Number Revision

\section{$N A$}

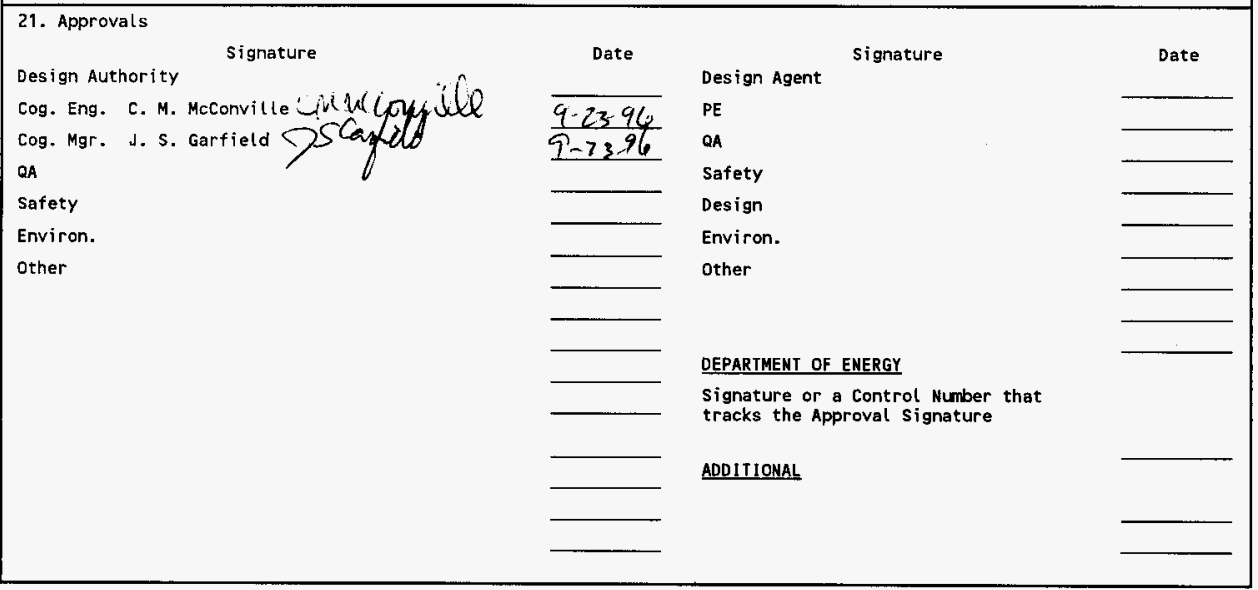




\title{
Decision Document for Function 4.2.4, Dispose Waste
}

\author{
C. M. McConville, K. D. Boomer, R. D. Claghorn, \\ E. A. Fredenburg, and M. E. Johnson \\ Westinghouse Hanford Company, Richland, WA 99352 \\ U.S. Department of Energy Contract DE-AC06-87RL10930 \\ EDT/ECN: $608760-634663$ UC: 721 \\ Org Code: $73520 \quad$ Charge Code: 05222 \\ B\&R Code: EW3130010 Total Pages: 26
}

Key Words: decision document

Abstract: This report formally documents the planning assumptions for Function 4.2.4, Dispose Waste, to provide a basis for lower leve1 Tank Waste Remediation System (TWRS) Disposal Program decisions and analyses. The TWRS Environmental Impact Statement (DOE/EIS 1996) and a supplemental Environmental Impact Statement for closure of operable units will provide the ultimate Records of Decision for the TWRS strategy at this level. However, in the interim, this decision document provides a formal basis for the TWRS Dispose Waste planning assumptions. Function 4.2 .4 addresses the disposition of immobilized high-level waste (IHLW), the disposition of immobilized low-activity waste (ILAW), and closure of the tank farm operable units.

TRADEMARK DISCLAIMER. Reference herein to any specific commercial product, process, or service by trade name, trademark, manufacturer, or otherwise, does not necessarily constitute or imply its endorsement, recommendation, or favoring by the United states Govermment or any agency thereof or its contractors or subcontractors.

Printed in the United States of America. To obtain copies of this document, contact: WHC/BCS

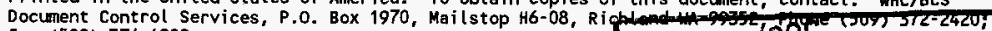
Fax (509) 376-4989.
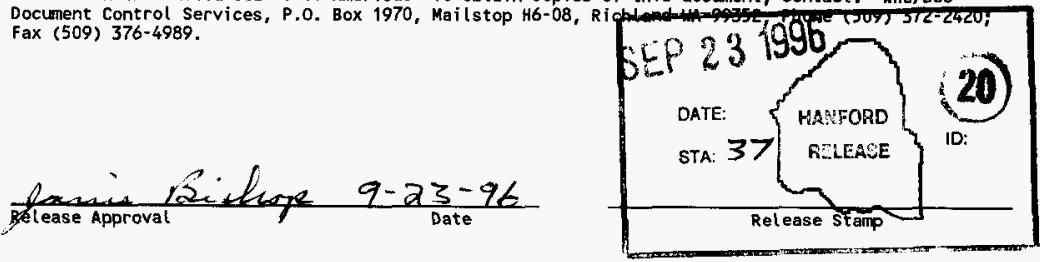

Approved for Public Release 


\section{RECORD OF REVISION}

(2) Title

Decision Document for Function 4.2.4, Dispose Waste CHANGE CONTROL RECORD

(3) Revision

0 (4) Description of Change - Replace, Add, and Delete

(7) Initial release. Corres. \#9652292 DPO-96-39. EDT 608760 .

1 RS ECN 634663 Incorporated DOE-RL Comments.
Authorized for Release

\begin{tabular}{l|l} 
(5) Cog. Engr. & (6) Cog. Mgr. Date \\
\hline
\end{tabular}

C. M. McConville J. S. Garfield

C. M. McConville

J. S. Garfield

cumscanile 
WHC-SD-WM-ES-381

Revision 1

\section{DECISION DOCUMENT FOR \\ FUNCTION 4.2.4, \\ DISPOSE WASTE}

C. M. McConville

K. D. Boomer

R. D. Claghorn

E. A. Fredenburg

M. E. Johnson

September 1996

Westinghouse Hanford Company

Richland, Washington 
WHC-SD-WM-ES-381

Revision 1

This page intentionally left blank. 
WHC-SD-WM-ES-381

Revision 1

CONTENTS

1.0 INTRODUCTION $\ldots \ldots \ldots \ldots \ldots \ldots \ldots \ldots \ldots \ldots \ldots \ldots$

2.0 STATEMENT OF THE PROBLEM $\ldots \ldots \ldots \ldots \ldots \ldots \ldots \ldots \ldots$

3.0 DATE OF SELECTION $\ldots \ldots \ldots \ldots \ldots \ldots \ldots \ldots \ldots \ldots$

4.0 DECISION MAKER $\ldots \ldots \ldots \ldots \ldots \ldots \ldots \ldots \ldots \ldots \ldots \ldots$

5.0 DECISION ACTION OFFICER $\ldots \ldots \ldots \ldots \ldots \ldots \ldots \ldots \ldots \ldots$

6.0 IMMOBILIZED HIGH-LEVEL WASTE DISPOSAL $\ldots \ldots \ldots \ldots \ldots \ldots \ldots$

6.1 ALTERNATIVE SELECTED AS PLANNING ASSUMPTION FOR HIGH-

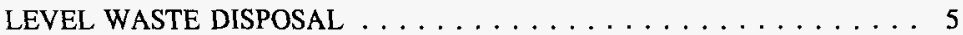

6.2 HIGH-LEVEL WASTE DISPOSAL DECISION CRITERIA AND RATIONALE FOR SELECTION $\ldots \ldots \ldots \ldots \ldots \ldots \ldots$

6.3 HIGH-LEVEL WASTE DISPOSAL ASSUMPTIONS $\ldots \ldots \ldots \ldots \ldots$

6.4 HIGH-LEVEL WASTE DISPOSAL ALTERNATIVE REJECTED $\ldots \ldots \ldots 6$

7.0 IMMOBILIZED LOW-ACTIVITY WASTE DISPOSAL . . . . . . . . . 7

7.1 ALTERNATIVE SELECTED AS PLANNING ASSUMPTION FOR

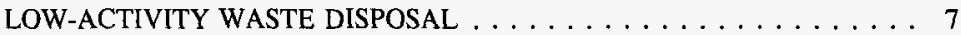

7.2 LOW-ACTIVITY WASTE DISPOSAL DECISION CRITERIA AND

RATIONALE FOR SELECTION $\ldots \ldots \ldots \ldots \ldots \ldots \ldots$

7.3 LOW-ACTIVITY WASTE DISPOSAL ASSUMPTIONS $\ldots \ldots \ldots \ldots .7$

7.4 LOW-ACTIVITY WASTE ALTERNATIVES REJECTED $\ldots \ldots \ldots \ldots .8$

8.0 CLOSURE OF OPERABLE UNITS . . . . . . . . . . . . . . 9

8.1 ALTERNATIVE SELECTED AS PLANNING ASSUMPTION FOR

CLOSURE OF OPERABLE UNITS . . . . . . . . . . . . 9

8.2 CLOSURE OF OPERABLE UNITS DECISION CRITERIA AND

RATIONALE FOR SELECTION $\ldots \ldots \ldots \ldots \ldots \ldots \ldots$

8.3 CLOSURE OF OPERABLE UNITS ASSUMPTIONS $\ldots \ldots \ldots \ldots \ldots$

8.3.1 Assumptions Supporting Selected Closure of Operable

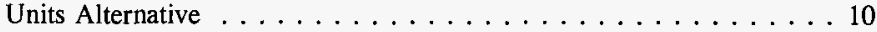

8.3.2 Similarities Among Closure of Operable Units Alternatives Evaluated . 12

8.3.3 Differences Among Closure of Operable Units Alternatives Evaluated . 13

8.4 CLOSURE OF OPERABLE UNITS ALTERNATIVES REJECTED . . . . 15

9.0 DECISION ACCEPTANCE $\ldots \ldots \ldots \ldots \ldots \ldots \ldots \ldots \ldots \ldots$

10.0 REFERENCES . . . . . . . . . . . . . . . . . . . . 19 
WHC-SD-WM-ES-381

Revision 1

\section{LIST OF TERMS}

$\begin{array}{ll}\text { DOE } & \text { U.S. Department of Energy } \\ \text { EIS } & \text { Environmental Impact Statement } \\ \text { IHLW } & \text { Immobilized high-level waste } \\ \text { ILAW } & \text { Immobilized low-activity waste } \\ \text { MTCA } & \text { Model Toxics Control Act } \\ \text { NEPA } & \text { National Environmental Protection Act } \\ \text { PA } & \text { Performance assessment } \\ \text { RCRA } & \text { Resource Conservation and Recovery Act of 1976 } \\ \text { RL } & \text { U.S. Department of Energy, Richland Operations Office } \\ \text { SRR } & \text { Systems requirements review } \\ \text { TWRS } & \text { Tank Waste Remediation System } \\ \text { WHC } & \text { Westinghouse Hanford Company }\end{array}$


WHC-SD-WM-ES-381

Revision 1

\section{DECISION DOCUMENT FOR FUNCTION 4.2.4, DISPOSE WASTE}

\subsection{INTRODUCTION}

This report formally documents the planning assumptions for Function 4.2.4, Dispose Waste. The Tank Waste Remediation System Environmental Impact Statement (TWRS-EIS) (DOE/EIS 1996) and a supplemental EIS for closure of operable units will provide the ultimate Records of Decision for the TWRS strategy at this level. However, in the meantime, this decision document provides a formal basis for lower level TWRS Disposal Program decisions and analyses.

Function 4.2.4 addresses the disposition of immobilized high-level waste (IHLW), the disposition of immobilized low-activity waste (ILAW), and closure of the tank farm operable units. Figure 1 shows the recommended architecture selection for Function 4.2.4, and its predecessor, Function 4.2, Remediate Tank Waste. Other related functions under Remediate Tank Waste include Function 4.2.1, Manage Tank Waste; Function 4.2.2, Retrieve Tank Waste; and Function 4.2.3, Process Tank Waste (includes waste separation and immobilization).

This decision document follows a decision analysis procedure that is consistent with the Systems Engineering approach recommended by the U.S. Department of Energy-Richland Operations Office (RL) and Westinghouse Hanford Company (WHC) (DOE 1995). In addition, the decision document satisfies recommendations from the TWRS systems requirements review (SRR) team (DOE/RL 1996). The TWRS SRR team noted two principal findings with regard to previous TWRS decision analysis methods:

1. "Processes for retrieval, pretreatment, and immobilization of wastes often have been based on unverified assumptions rather than being selected from the results of defensible analyses of viable alternatives" (DOE/RL 1996, Summary of Findings).

2. "None of the decisions were supported by documented technically defensible data and analysis" (DOE/RL 1996, Section 2.2.6).

The decision analysis procedure complies with the recommendations of the SRR team by "...conducting verifiable alternatives analyses and sensitivity analyses to define and document a robust architecture for TWRS that avoids delays, is not vulnerable to single-point failures, meets stakeholder expectations, and significantly improves performance" (DOE/RL 1996, General Recommendations). An initial evaluation is performed that screens alternatives against a pre-approved set of decision criteria. The results are then presented to a decision maker who selects the preferred alternative. This report clearly states the decision and documents the preferred alternative, alternatives considered, decision criteria, rationale for selection, and assumptions. 


\section{WHC-SD-WM-ES-381}

\section{Revision 1}

Figure 1. Architecture Selection for Tank Waste Remediation System Functions 4.2 and 4.2.4.

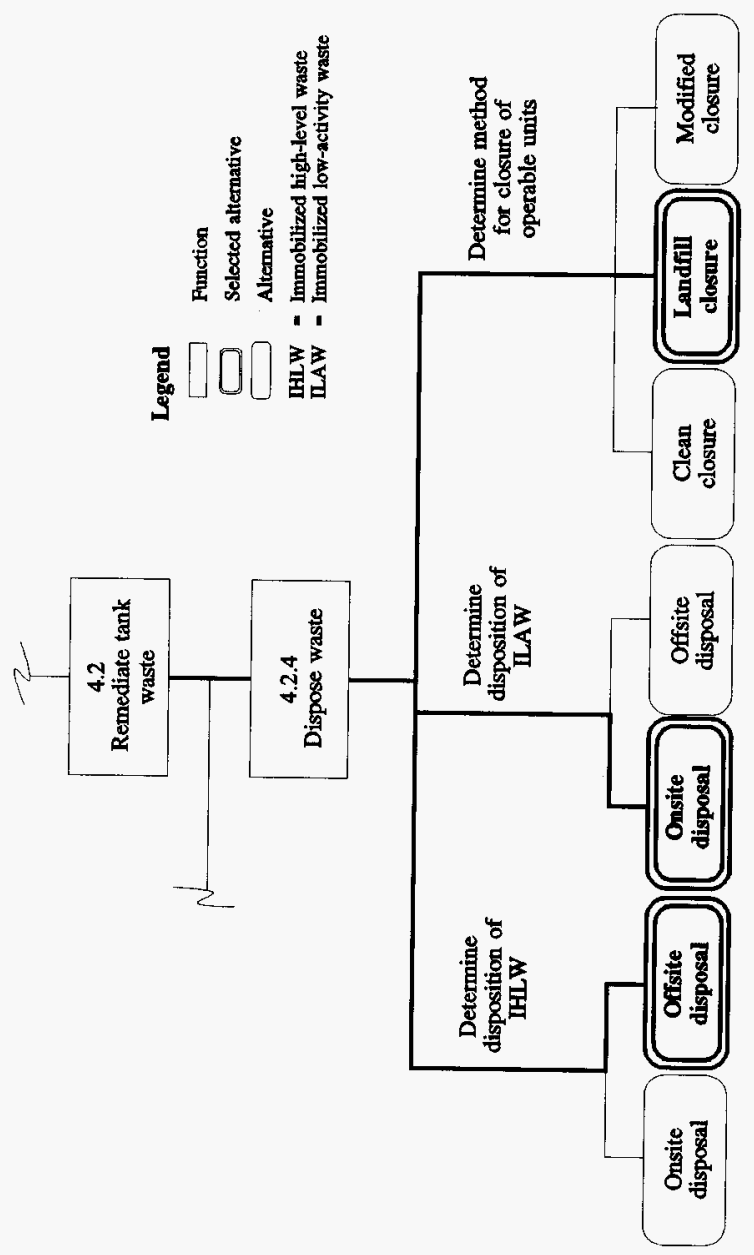


WHC-SD-WM-ES-381

Revision 1

\subsection{STATEMENT OF THE PROBLEM}

The disposal baseline consists of three components: (1) disposal of IHLW, (2) disposal of ILAW, and (3) closure of tank farm operable units. Function 4.2 .4 addresses the following questions:

1. Will the IHLW be disposed onsite or offsite?

2. Will the ILAW be disposed onsite or offsite?

3. Will the operable units be closed according to requirements for clean closure, landfill closure, or modified closure?

\subsection{DATE OF SELECTION}

The formal decision document for Function 4.2 .4 was signed by the decision maker May 31, 1996. See Section 8.0, Decision Acceptance.

\subsection{DECISION MAKER}

The decision maker reviews the decision analysis and forwards a recommendation to RL. J. O. Honeyman is the responsible WHC decision maker.

\subsection{DECISION ACTION OFFICER}

The action officer is responsible for ensuring the decision analysis is conducted in accordance with system engineering principles. The action officer presents the results of the decision analysis to the decision maker for review and approval. J. S. Garfield is the decision action officer. 
WHC-SD-WM-ES-381

Revision 1

This page intentionally left blank. 
WHC-SD-WM-ES-381

Revision 1

\subsection{IMMOBILIZED HIGH-LEVEL WASTE DISPOSAL}

This section documents the IHLW disposal portion of the Function 4.2.4 decision. Two IHLW disposal alternatives were screened for compliance with regulatory constraints. The two alternatives included: (1) onsite disposal of Hanford IHLW, and (2) offsite disposal of Hanford IHLW.

\subsection{ALTERNATIVE SELECTED AS PLANNING ASSUMPTION FOR HIGH-LEVEL WASTE DISPOSAL}

The planning assumption for the disposal of IHLW will send the treated waste (including the waste products of dispositioned cesium and strontium capsules) to an offsite geological repository. However, interim storage of IHLW at the Hanford Site must be provided until the waste is accepted by DOE for disposal at the offsite repository.

\subsection{HIGH-LEVEL WASTE DISPOSAL DECISION CRITERIA AND RATIONALE FOR SELECTION}

The criterion used to distinguish among the high-level waste (HLW) disposal alternatives is the Nuclear Waste Policy Act (NWPA). The NWPA of 1982 (Public Law 97-425, January 7,1983 ) supported the development of repositories for the disposal of HLW and spent nuclear fuel. The NWPA of 1982 contained a requirement for the President to evaluate the use of commercial repository capacity for the disposal of defense HLW (NWPA, section 8[b]). The Secretary of Energy, Donald Hodel, recommended to President Reagan in 1985 that the DOE proceed with plans and actions to dispose of defense waste in a commercial repository. The Secretary's recommendation was based on a U.S. DOE document entitled An Evaluation of Commercial Capacity for the Disposal of Defense HighLevel Waste (DOE 1985). The DOE document performs a comparative evaluation of disposing the HLW in a commercial repository or defense-only repository, and contains the Secretary's recommendation as an attachment.

The first amendment to the NWPA, the Nuclear Waste Policy Amendments Act of 1987 (Public Law 100-203), identified the Yucca Mountain site in Nevada as the only candidate site being evaluated for construction of a repository for the disposal of IHLW and spent nuclear fuel. In addition, the NWPA requires generators and owners of HLW to provide for the interim storage of such waste until the waste is accepted by the DOE for disposal at a repository (NWPA, section 111[a][5]).

As a result of the NWPA and its amendments, the recommended IHLW disposal planning assumption is to dispose of the waste at an offsite repository, and would also require interim storage of the IHLW onsite until the waste is accepted by DOE at the repository. 


\subsection{HIGH-LEVEL WASTE DISPOSAL ASSUMPTIONS}

The recommended planning assumption for disposal of IHLW is based on the assumptions discussed below:

Hanford Shipments to Offsite Geological Repository will Follow Shipments From Other DOE Sites. The HLW geological repository is scheduled to begin receipt of IHLW beginning in 2015 (DOE 1994, item 3.2.1.3). It is anticipated that IHLW will be initially received at the repository from other DOE sites (i.e., West Valley Demonstration Project and Savannah River Site) because these sites will have already initiated immobilization operations.

Sufficient Onsite Interim Storage Capacity. It is assumed that sufficient interim storage capacity will be provided at the Hanford Site for all the IHLW canisters, the product from the disposition of cesium and strontium capsules, and any miscellaneous HLW materials.

Monitoring of Interim-Stored IHLW Canisters. The IHLW canisters will be monitored while at the interim storage facility. Canisters that are determined not to comply with geologic repository waste acceptance criteria will be evaluated for re-work at the HLW immobilization facility, re-packaging, or acceptance by the geological repository as a non-standard waste form.

\subsection{HIGH-LEVEL WASTE DISPOSAL ALTERNATIVE REJECTED}

The IHLW disposal alternative to dispose of IHLW onsite was screened out based on the NWPA and its amendments. The onsite IHLW disposal alternative would receive IHLW from the Hanford waste treatment facilities and transport the IHLW to a permanent disposal facility located at the Hanford Site. 
WHC-SD-WM-ES-381

Revision 1

\subsection{IMMOBILIZED LOW-ACTIVITY WASTE DISPOSAL}

This section documents the ILAW disposal portion of the Function 4.2.4 decision. Two ILAW disposal alternatives were screened for compliance with regulatory constraints. The two alternatives included: (1) onsite disposal of Hanford ILAW, and (2) offsite disposal of Hanford ILAW.

\subsection{ALTERNATIVE SELECTED AS PLANNING ASSUMPTION FOR LOW-ACTIVITY WASTE DISPOSAL}

The recommended planning assumption for ILAW disposal will dispose of the waste in a near-surface engineered disposal facility at the Hanford Site. The ILAW from tank waste treatment facilities will be stored and, if required, transferred to other onsite facilities for disposal.

\subsection{LOW-ACTIVITY WASTE DISPOSAL DECISION CRITERIA AND RATIONALE FOR SELECTION}

The criterion used to distinguish among the LAW disposal alternatives is DOE Order 5820.2A, Radioactive Waste Management (DOE 1989). The Order states it is DOE's policy to dispose of DOE ILAW on the site at which it is generated, if practical, or if onsite disposal capability is not available, transport to another DOE disposal facility (DOE Order 5820.2a, chapter III, Section 2.c).

The Hanford Site is believed to be capable of providing an ILAW disposal facility, and it is practical to dispose of the ILAW onsite. Therefore, as a result of DOE Order 5820.2A, the recommended ILAW disposal planning assumption is to dispose of the waste on the Hanford Site.

\subsection{LOW-ACTIVITY WASTE DISPOSAL ASSUMPTIONS}

The recommended planning assumption for disposal of ILAW is based on the assumptions discussed below:

ILAW Storage/Disposal Facility Conceptual Architecture will Enable Retrieval and Repackaging of ILAW Containers. The Hanford Site stakeholders have expressed the desire to use "... retrievable waste forms when potential hazards from the waste may require future retrieval and when retrievability does not cause inordinate delays in getting on with cleanup..." (Drummond 1993, pg. 11). This stakeholder value has been interpreted to mean the disposal facility will be designed to allow for future retrieval and repackaging of the ILAW containers for up to 50 years after emplacement 
of the containers, if necessary. The structure of the ILAW containers will allow for crane and/or forklift handling. In the event of package failure, the ILAW may be retrieved and repackaged within reasonable dose limits to workers using presently available technology.

\section{ILAW Performance Assessment Will Determine Disposal Location of ILAW} Containers. The ILAW containers will be stored until a performance assessment (PA) has been completed. The results of the PA will determine if the stored ILAW will be moved to a disposal facility. The ILAW storage/disposal facilities will receive containers from June 2002 through calendar year 2024, after which closure of the facility will be conducted.

\subsection{LOW-ACTIVITY WASTE ALTERNATIVES REJECTED}

The ILAW disposal alternative to dispose of ILAW offsite was screened out based on the DOE Order 5820.2A, since ILAW disposal capability is available at the Hanford Site. The offsite ILAW disposal alternative would transport ILAW from Hanford waste treatment facilities to a disposal facility located at another DOE site or a commercially licensed LAW disposal facility. 
WHC-SD-WM-ES-381

Revision 1

\subsection{CLOSURE OF OPERABLE UNITS}

This section documents the closure of operable units portion of the Function 4.2.4 decision. Three alternatives for closure of operable units were screened for compliance with regulatory constraints. The three alternatives included: (1) clean closure, (2) modified closure, and (3) landfill closure.

\subsection{ALTERNATIVE SELECTED AS PLANNING ASSUMPTION FOR CLOSURE OF OPERABLE UNITS}

The recommended planning assumption for closure of operable units is landfill closure. Closure of operable units as a landfill is an interim assumption for planning and budgeting purposes until the environmental impacts have been assessed and public input has been received through the National Environmental Protection Act (NEPA) process.

Landfill closure must satisfy the requirements of the General Closure Performance Standard (WAC 173-303-610(2)(a)), the Closure Standard for Tank Systems (WAC 173-303-640(8)), and Chapter III of DOE Order 5820.2A. In addition, landfill closure must satisfy WAC 173-303-665(6)(a) and WAC 173-303-610(7)(a), which require a surface barrier and a post-closure monitoring period of 30 years.

\subsection{CLOSURE OF OPERABLE UNITS DECISION CRITERIA AND RATIONALE FOR SELECTION}

The criteria used to distinguish among the closure of operable units alternatives consists of five current program assumptions established for planning and budgeting purposes. Explanations of each are provided in Section 8.3.

1. Residual waste will remain in the tanks ( 99 percent removal of tank wastes).

2. The tanks will remain in the ground.

3. The tanks will be filled to prevent subsidence.

4. Surface barriers will be constructed to prevent the spread of contamination.

5. The soil surrounding the tanks will not be remediated.

Of the three closure alternatives assessed, landfill closure is the most likely to satisfy all of the above conditions. Condition 5 (soil surrounding the tanks will not be remediated) rules out clean or modified closure of operable units. Closure studies are planned for fiscal year 1997 to evaluate the validity of the five assumed conditions. The 1997 closure studies 
WHC-SD-WM-ES-381

Revision 1

are to be identified in a revision to the fiscal year 1996 TWRS Multi-Year Program Plan (WHC 1995). The results of the 1997 closure studies will serve as input to the supplemental NEPA analysis of closure alternatives discussed previously.

\subsection{CLOSURE OF OPERABLE UNITS ASSUMPTIONS}

The assumptions for closure of operable units have been organized into three categories: (1) assumptions supporting the selected alternative, (2) similarities among the alternatives evaluated, and (3) differences among the alternatives evaluated. The last two categories are included to clarify the current interpretation of the terms "Clean Closure," "Modified Closure," and "Landfill Closure."

\subsubsection{Assumptions Supporting Selected Closure of Operable Units Alternative}

The recommended planning assumption for closure of operable units is based on the assumptions discussed below:

Hanford operable unit definition. An operable unit at Hanford is defined in the Hanford Federal Facility Agreement and Consent Order (Tri-Party Agreement) (Ecology et al. 1994) as "a group of land disposal sites placed together for the purposes of doing a Remedial Investigation/Feasibility Study and subsequent cleanup actions. The primary criteria for placement of a site into an operable unit includes geographic proximity, similarity of waste characteristics and site type." A listing of the Hanford Site operable units is provided in Appendix C of the Tri-Party Agreement.

Residual waste will remain in the tanks ( 99 percent removal of tank wastes). The Tri-Party Agreement Milestone M-45-00 (Ecology et al. 1994) states, "closure will follow retrieval of as much tank waste as technically possible, with tank waste residues not to exceed $10.2 \mathrm{~m}^{3}\left(360 \mathrm{ft}^{3}\right)$ in each of the 100 series tanks, $0.85 \mathrm{~m}^{3}\left(30 \mathrm{ft}^{3}\right)$ in each of the 200 series tanks, or the limit of waste retrieval technology capability, whichever is less." This volume of tank waste residues equates to approximately one percent of the total waste inventory in the tanks.

Residual Waste Complies with Regulations for Near-Surface Disposal. Retrieval removes waste from tanks to the extent necessary to meet Tri-Party Agreement Milestone M-45-00 criteria. The residual waste will be classified by the NRC as non-HLW, and therefore would not require a HLW disposal site license.

The tanks will remain in the ground. It has been determined that full retrieval and treatment of empty tanks and surrounding soil is cost prohibitive relative to the environmental benefits gained (Boomer et al. 1993, Chapters 10.0 and 11.0). If waste residues remain in the tanks, costly tank-farm confinement facilities would be required to remove the tanks from the ground. Table 10-1 of the Technical Options Report 
shows a life-cycle cost range of $\$ 2.8$ to $\$ 3.1$ billion (1993) dollars to remove the tanks, depending on the chosen confinement facility. Table 11-1 shows a life-cycle cost range of $\$ 2.8$ to $\$ 3.0$ billion (1993) dollars to remediate the soil and debris, depending on the treatment method selected. Closure studies are planned for fiscal year 1997 to further evaluate the validity of this assumption. The 1997 closure studies are to be identified in a revision to the fiscal year 1996 TWRS Multi-Year Program Plan (WHC 1995). The results of the 1997 closure studies will serve as input to the supplemental NEPA analysis of closure alternatives previously mentioned.

The tanks will be stabilized with an engineered fill and surface barriers constructed. If the tanks remain in the ground, a surface barrier will be placed to limit water infiltration and contaminant transport. The tanks will be stabilized with an engineered fill to prevent eventual tank subsidence and resultant degradation of the surface barrier.

Soil Surrounding Leaking Tanks Will Not be Decontaminated. Waste has leaked from many of the SSTs, resulting in contamination of the soil beneath the tanks. Washing or excavation of the soil to remove contaminants will not be undertaken. Decontamination of the soil surrounding the SSTs would require removal of the tank shells and the complete removal of waste from the underground storage tanks. Complete removal of tank waste is not included in the current retrieval baseline, and is not required by existing regulations, federal law, or the Tri-Party Agreement. Closure studies are planned for fiscal year 1997 to further evaluate the validity of this assumption. The 1997 closure studies are to be identified in a revision to the fiscal year 1996 TWRS Multi-Year Program Plan (WHC 1995). The results of the 1997 closure studies will serve as input to the supplemental NEPA analysis of closure alternatives previously mentioned.

Final Plan for Closure of Operable Units to be Issued by Ecology before September 30, 2006. A closure work plan will be developed with the Ecology in accordance with Tri-Party Agreement Milestone M-45-06. A tank closure/post-closure plan to demonstrate closure of a selected operable unit will be submitted to Ecology for approval by November 30, 2004. Ecology will issue the final plan for closure of the selected operable unit by September 30, 2006 (Ecology et al. 1994).

Final Disposal Decision will be Provided by an EIS-ROD. The ROD for the TWRSEIS (DOE/EIS 1996) will provide the final decision for the disposition of IHLW and ILAW. Alternatives for closure of operable units will be evaluated in a supplement to the TWRS-EIS. The ROD to the supplemental EIS will provide the final decision on closure of operable units. However, in the interim, this decision document provides a technical basis for conducting further evaluations. 
WHC-SD-WM-ES-381

Revision 1

\subsubsection{Similarities Among Closure of Operable Units Alternatives Evaluated}

Each closure of operable units alternative is subject to the following three requirements:

1. WAC 173-303-610(2)(a), general closure performance standard

The Hanford Site RCRA Permit (Ecology 1995) states the facility shall be closed according to the General Closure Performance Standard, WAC 173-303-610(2)(a) in a manner that minimizes the need for further maintenance and controls, and minimizes or eliminates, to the extent necessary, to protect human health and the environment, postclosure escape of dangerous waste, dangerous constituents, leachate, contaminated run-off, or dangerous waste decomposition products to the ground, surface water, ground water, or the atmosphere; returns the land to the appearance and use of surrounding land areas to the degree possible given the nature of the previous dangerous waste activity.

2. WAC 173-303-640(8), closure and postclosure care of tank systems

The closure standard for tank systems, WAC 173-303-640(8), serves as a discriminator for the regulatory closure alternatives. If the operator demonstrates that all contaminated soils can be practicably removed or decontaminated, then the tank system must be closed in accordance with the Model Toxics Control Act (MTCA) (WAC 173-340). If not all contaminated soils can be practicably removed or decontaminated, then the tank system must be closed in accordance with landfill requirements (173-303-665(6)).

\section{DOE Order 5820.2A, Chapter III}

Chapter III of DOE Order 5820.2A states that disposal sites shall prepare and maintain a site specific radiological performance assessment for the disposal of waste to: (1) protect public health and safety; (2) assure that external exposure to the waste does not exceed $25 \mathrm{mrem} / \mathrm{yr}$ to any member of the public; (3) assure that 100 years after closure an individual exposed to the facility will not receive more than $100 \mathrm{mrem} / \mathrm{yr}$ for continuous exposure or $500 \mathrm{mrem}$ for a single acute exposure. 


\subsubsection{Differences Among Closure of Operable Units Alternatives Evaluated}

The requirements that differentiate the closure alternatives were determined from the Hanford Site Resource Conservation and Recovery Act of 1976 (RCRA) Permit (Ecology 1995). The RCRA permit lists the following performance standards for soil/groundwater closure:

- Clean closure cleanup levels are specified by WAC 173-303-610(2)(b), or background levels, whichever is greater, (Ecology 1995, Conditions II.K.1 and II.K.2). WAC 173-303-610(2)(b) specifies Method B of the Model Toxics Control Act (MTCA), as defined by WAC 173-340. MTCA Method B is the standard method for determining cleanup levels for ground water, surface water, soil, and air. Method B cleanup levels are based upon the upper bound of the estimated excess lifetime cancer risk of one in one million $\left(1 \times 10^{-6}\right)$ for individual carcinogens. If more than one type of hazardous substance is present and/or pathways of exposure, the total excess cancer risk for a site shall not exceed one in one hundred thousand $\left(1 \times 10^{-5}\right)$.

- Landfill closure cleanup levels are specified by WAC 173-303-610, general closure performance standard (Ecology 1995, Condition II.K.4).

- Modified closure cleanup levels are specified under MTCA Method C of WAC 173-340 (Ecology 1995, Condition II.K.3). Method C is a conditional method that is used when cleanup levels under Method B are impossible to achieve, are lower than background concentrations, or may cause more environmental harm than good. MTCA Method C is similar to Method B. The main difference is that the lifetime cancer risk is set at one in one hundred thousand $\left(1 \times 10^{-5}\right)$ for both individual substances and for the total risk caused by all substances on a site.

Table 1 lists the requirements for each of the closure alternatives. 


\section{Revision 1}

Table 1. Requirements for Regulatory Closure Alternatives.

\begin{tabular}{|c|c|c|c|}
\hline & Cleanup standards ${ }^{a}$ & $\begin{array}{l}\text { Surface } \\
\text { barrier }\end{array}$ & $\begin{array}{l}\text { Post-closure } \\
\text { monitoring } \\
\text { period }\end{array}$ \\
\hline \multirow{4}{*}{$\begin{array}{l}\text { Clean } \\
\text { closure }\end{array}$} & General Closure Performance Standard, WAC 173-303-610(2)(a) & \multirow{4}{*}{$\begin{array}{l}\text { Not } \\
\text { required }\end{array}$} & \multirow{4}{*}{ None } \\
\hline & Closure Standard for Tank Systems, WAC $173-303-640(8)^{\circ}$ & & \\
\hline & DOE Order $5820.2 \mathrm{~A}$, Chapter IIIf & & \\
\hline & $\begin{array}{l}\text { Model Toxics Control Act (MTCA) (WAC 173-340) Method B } \\
\text { cleanup levels: }\end{array}$ & & \\
\hline \multirow[t]{3}{*}{$\begin{array}{l}\text { Landfill } \\
\text { closure }\end{array}$} & $\begin{array}{l}\text { General Closure Performance Standard, WAC 173-303- } \\
610(2)(\mathrm{a})^{\mathrm{b}, \mathrm{c}}\end{array}$ & \multirow[t]{3}{*}{ Requiredg $^{g}$} & \multirow[t]{3}{*}{30 years $^{h}$} \\
\hline & Closure Standard for Tank Systems, WAC 173-303-640(8) & & \\
\hline & DOE Order $3820.2 \mathrm{~A}$, Chapter III & & \\
\hline \multirow{4}{*}{$\begin{array}{l}\text { Modified } \\
\text { closure }\end{array}$} & General Closure Performance Standard, WAC 173-303-610(2)(a) & \multirow{4}{*}{$\begin{array}{l}\text { Not } \\
\text { required }\end{array}$} & \multirow[t]{4}{*}{5 years $^{\mathrm{i}}$} \\
\hline & Closure Standard for Tank Systems, WAC $173-303-640(8)^{\circ}$ & & \\
\hline & DOE Order $5820.2 \mathrm{~A}$, Chapter $\mathrm{II}^{f}$ & & \\
\hline & MTCA (WAC 173-340) Method C cleanup levelis: & & \\
\hline
\end{tabular}

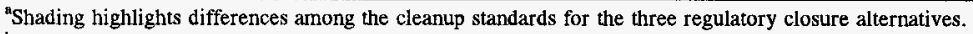

bHanford Site RCRA Permit Performance Standards for Facility Closure state the Facility shall be closed according to the General Closure Performance Standard, WAC 173-303-610(2)(a) (see Section 7.3).

"Hanford Site RCRA Permit Performance Standards for Soil/Groundwater Closure (Ecology 1995):

- Clean Closure cleanup levels are specified by WAC 173-303-610(2)(b) or background levels, whichever is greater, (Conditions II.K.1 and II.K.2).

- Modified Closure cleanup levels are specified under Method C of WAC 173-340 (Condition II.K.3).

- Landfill Closure cleanup levels are specified by WAC 173-303-610 (Condition II.K.4).

${ }^{d}$ Model Toxics Control Act (MTCA), WAC 173-340, defines Method B and Method C as follows:

MTCA (WAC 173-340) Method B cleanup levels:

- Lifetime cancer risk cannot exceed 1-in-1,000,000 for individual carcinogens

- If more than one hazardous substance present, total lifetime cancer risk cannot exceed 1-in-100,000.

MTCA (WAC 173-340) Method C cleanup levels:

- Used when cleanup levels under Method B are impossible to achieve, are lower than background concentrations, or may cause more environmental harm than good.

- Lifetime cancer risk cannot exceed 1-in-100,000 for individual carcinogens

- If more than one hazardous substance present, total lifetime cancer risk cannot exceed 1-in-100,000.

'WAC 173-303-640(8) states that if all contaminated soils can be practicably removed or decontaminated, then the tank system must be closed in accordance with MTCA (WAC 173-340). If not all contaminated soils can be removed, the tank system must be closed in accordance with landfill requirements (173-303-665(6)).

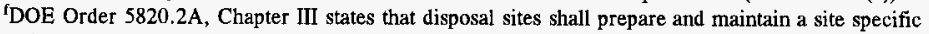
radiological performance assessment for the disposal of waste (see section 7.3).

gWAC 173-303-665(6)(a) states an operable unit closed as a landfill must be covered with a surface barrier.

${ }^{n}$ WAC 173-303-610(7)(a) states ground water monitoring, and maintenance and monitoring of waste containment systems must continue for 30 years after completion of landfill closure.

${ }^{i}$ Hanford Site RCRA Permit Condition II.K.3 states access to the operable unit will be restricted for a minimum of tive years following completion of modified closure. If periodic assessments identify contamination above the allowable limits, the units must be further remediated or the requirements of landfill closure must be followed. 
WHC-SD-WM-ES-381

Revision 1

\subsection{CLOSURE OF OPERABLE UNITS ALTERNATIVES REJECTED}

The clean and modified closure alternatives were screened out based on the assumption that the soil surrounding the tanks will not be remediated. A comparison of clean, modified, and landfill closure is provided above in section 8.3. 
WHC-SD-WM-ES-381

Revision 1

This page intentionally left blank. 


\subsection{DECISION ACCEPTANCE}

The planning assumptions for Function 4.2.4, Dispose Waste, are as follows:

1. The IHLW (including waste products of dispositioned cesium/strontium capsules) will be disposed at a geologic repository located offsite. However, interim storage of IHLW at the Hanford Site will be provided until the waste is accepted by DOE for disposal at the offsite repository (NWPA, section III[a][5]).

2. The ILAW will be stored onsite then disposed at a near-surface engineered disposal facility at the Hanford Site (DOE Order 5820.2A).

3. The tank farm operable units will be closed as a landfill in accordance with WAC 173-303-610(2)(a), 173-303-640(8) and DOE Order 5820.2A.

The recommended planning assumptions for the disposal of IHLW and ILAW are consistent with the preferred alternative for treatment and disposal of Hanford tank wastes as described in the Draft TWRS-EIS (DOE/EIS 1996). The ROD for the TWRS-EIS will provide the final decision for the TWRS strategy for disposal of IHLW and ILAW at this level. Alternatives for closure of operable units will be evaluated in a supplement to the TWRS-EIS. The ROD to the supplemental EIS will provide the final decision on closure of operable units. However, in the interim, this decision document provides a basis for conducting further evaluations.

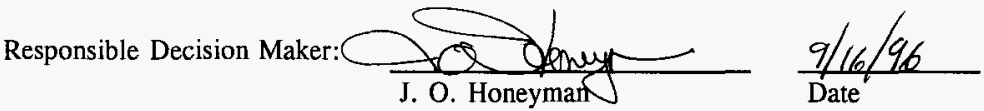

Decision Action Officer:

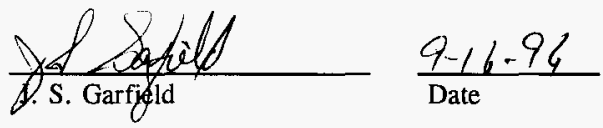


WHC-SD-WM-ES-381

Revision 1

This page intentionally left blank. 
WHC-SD-WM-ES-381

Revision 1

\subsection{REFERENCES}

Boomer, K. D., S. K. Baker, A. L. Boldt, J. D. Galbraith, J. S. Garfield, C. E. Golberg, B. A. Higley, L. J. Johnson, M. J. Kupfer, R. M. Marusich, R. J. Parazin, A. N. Praga, G. W. Reddick, J. A. Reddick, E. J. Slaathaug, L. M. Swanson, T. L. Waldo, and C. E. Worcester, 1993, Tank Waste Technical Options Report, WHC-EP-0616, Westinghouse Hanford Company, Richland, Washington.

DOE, 1985, An Evaluation of Commercial Repository Capacity for the Disposal of Defense High-Level Waste, DOE/DP/0020/1, U.S. Department of Energy, Washington, D.C.

DOE, 1989, Radioactive Waste Management, DOE Order 5820.2A, U.S. Department of Energy, Washington, D.C.

DOE, 1994, Waste Acceptance System Requirements Document (WASRD), DOE/RW-0351P, Rev. 1, U.S. Department of Energy Office of Civilian Radioactive Waste Management, Washington, D.C.

DOE, 1995, J. E. Kinzer, Tank Waste Remediation System (TWRS) Systems Engineering Management Policy, (Letter \#95-RTI-107 to President, Westinghouse Hanford Company, October 31, 1995) U.S. Department of Energy, Richland Operations Office, Richland, Washington.

DOE, 1996, Tank Waste Remediation System Privatization Request for Proposals (RFP), RFP No. DE-RP06-96RL13308, U.S. Department of Energy, Richland, Washington.

DOE/EIS, 1996, Tank Waste Remediation System Environmental Impact Statement, DOE/EIS-0189D, U.S. Department of Energy and Washington State Department of Ecology, Richland, Washington.

DOE/RL, 1996, Tank Waste Remediation System Requirements Review Action Plan, DOE/RL-95-74, Rev. 2, United States Department of Energy, Richland, Washington.

Drummond, M. E., 1993, Final Report Hanford Tank Waste Task Force, September 1993, U. S. Department of Energy, Richland, Washington.

Ecology, EPA, and DOE, 1994, Hanford Federal Facility Agreement and Consent Order, as amended, Washington State Department of Ecology, U.S. Environmental Protection Agency, and the U.S. Department of Energy, Olympia, Washington.

Ecology, 1995, Dangerous Waste Portion of the Resource Conservation and Recovery Act Permit for the Treatment, Storage, and Disposal of Dangerous Waste, Rev. 2, WA 7890008967, Hanford Facility, Washington State Department of Ecology, Olympia, Washington. 
WHC-SD-WM-ES-381

Revision 1

National Environmental Policy Act of 1969, 42 USC 4321 et seq.

Nuclear Waste Policy Act, Public Law 97-425, January 7, 1983.

Nuclear Waste Policy Amendments Act of 1987, Public Law 100-203, December 22, 1987, 42 USC 10101 et seq.

Resource Conservation and Recovery Act of 1976, 42 USC 6901 et seq.

WAC 173-303, 1995, "Dangerous Waste Regulations," Washington Administrative Code, as amended, Washington State Department of Ecology, Olympia, Washington.

WAC 173-340, 1991, "Model Toxics Control Act Cleanup Regulations," Washington Administrative Code, as amended, Washington State Department of Ecology, Olympia, Washington.

WHC, 1995, Tank Waste Remediation System Multi-Year Program Plan, WHC-SP-1101, Rev. 1A, Westinghouse Hanford Company, Richland, Washington. 


\begin{tabular}{|c|c|c|c|c|c|}
\hline \multicolumn{6}{|c|}{ DISTRIBUTION SHEET } \\
\hline & \multirow{2}{*}{\multicolumn{2}{|c|}{$\begin{array}{l}\text { From } \\
\text { C. M. McConville }\end{array}$}} & & \multicolumn{2}{|c|}{ Page 1 of 1} \\
\hline Distribution & & & & \multicolumn{2}{|c|}{ Date $9 / 18 / 96$} \\
\hline \multicolumn{3}{|l|}{ Project Title/Work Order } & & \multicolumn{2}{|c|}{ EDT No. } \\
\hline \multicolumn{3}{|c|}{$\begin{array}{l}\text { Decision Document for Function } 4.2 .4 \text {, Dispose Waste, } \\
\text { WHC-SD-WM-ES-381, Rev. } 1\end{array}$} & & \multicolumn{2}{|c|}{ ECN No. 634663} \\
\hline Name & MSIN & $\begin{array}{c}\text { Text } \\
\text { With All } \\
\text { Attach. }\end{array}$ & Text Only & $\begin{array}{l}\text { Attach./ } \\
\text { Appendix } \\
\text { Only }\end{array}$ & $\begin{array}{l}\text { EDT/ECN } \\
\text { Oniy }\end{array}$ \\
\hline $\begin{array}{l}\text { Central Files ( } 2 \text { copies) } \\
\text { DOE Reading Room }\end{array}$ & $\begin{array}{l}\text { A3-88 } \\
\mathrm{H} 2-53\end{array}$ & $\begin{array}{l}X \\
X\end{array}$ & & & \\
\hline $\begin{array}{l}\text { S. K. Baker } \\
\text { N. R. Brown (DOE) } \\
\text { D. D. Button } \\
\text { R. D. Claghorn } \\
\text { D. J. Francis (DOE) } \\
\text { E. A. Fredenburg } \\
\text { J. S. Garfield } \\
\text { J. O. Honeyman } \\
\text { E. J. Kosiancic } \\
\text { P. E. Lamont (DOE) } \\
\text { C. M. McConville (3 copies) } \\
\text { G. A. Meyer } \\
\text { R. J. Murkowski } \\
\text { R. W. Powell } \\
\text { P. S. Schaus } \\
\text { W. J. Taylor (DOE) } \\
\text { C. D. West (DOE) }\end{array}$ & $\begin{array}{l}\text { H5-49 } \\
\text { K6-51 } \\
\text { K6-51 } \\
H 5-49 \\
\text { K6-51 } \\
H 5-61 \\
\text { H5-49 } \\
\text { G3-21 } \\
\text { H5-61 } \\
\text { S7-53 } \\
\text { H5-49 } \\
\text { S2-48 } \\
\text { H5-03 } \\
H 4-14 \\
\text { G3-21 } \\
\text { K6-51 } \\
\text { S7-53 }\end{array}$ & $\begin{array}{l}X \\
X \\
X \\
X \\
X \\
X \\
X \\
X \\
X \\
X \\
X \\
X \\
X \\
X \\
X \\
X \\
X \\
X\end{array}$ & & & \\
\hline
\end{tabular}

